\title{
Study on Market Regulation in the View of Social Co-Governance
}

\author{
Hui Liu \\ Sub-Institute of Standardization Theory and Strategy \\ China National Institute of Standardization, \\ Beijing, China \\ liuhui2604@163.com
}

\begin{abstract}
The market regulator shall address a major issue regarding how to establish a market regulation system which conforms to the requirement of developing a unified, open, compe titive and orderly modern market system. For this purpose, this paper proposes the regulatory approach of combining the strength from government, market and society to jointly implement the market regulation through social co-governance. Besides, this paper also demonstrates the rise and reconstruction of regulatory state, and discusses the features of regulatory state in the context of China. Furthermore, this paper sugges ts that the effective market regulation needs to focus on the commonality of regulatory objectives, diversification of regulatory methods, regulatory transparency \& accountability, and diversification of regulatory body, and other factors. Moreover, this paper also discusses the social control system under the effective regulation, and proposes the "Multi-Subject Co-Governance" pattern within the market field. Such "Multi-Subject Co-Governance" pattern shall not only include the active engagement of public administration authority, but also include the active engagement of social organizations and individuals. Meanwhile, it shall not only include the command, enforcement and other formal regulatory methods used by the public authority, but also include the equal negotiation, social self-governance, public engagement and other informal methods. Finally, this paper also analyzes and demonstrates the self-discipline-based first-party control, the consensus-based second-party control, and the external-forcebased third-party control.
\end{abstract}

Keywords-Market Regulation, Regulatory State, Regulation Modernization, Social Co-Governance

\section{INTRODUCTION}

In general, the phrase "Market Regulation" demonstrates the administration-oriented, mandatory, and compulsory features in China's traditional economic and social operations. However, after years of development from the economic base to the superstructure, its connotation has already been entirely different from the past. During the commercial system reform process, the practice of loosening the pre-event market access, but strengthening the interim and post-event regulation, which confers the new connotation to such phrase "Regulation”. In view of this point, the concept and logic of regulatory state extensively accepted by people in developed market economy, has already been intentionally or unintentionally practiced by our commercial system reform. One of the obvious features of regulatory effectiveness stressed by regulatory state is the multi-subject co-governance with the multi-subject participation and multi-method simultaneous application [1]. The market regulation transforms from the overall regulation to effective regulation, which liberates the government from the tedious specific matters and lets the market and society to handle those matters that falls within their capability. If the multi-subject function can fully come into play, it will help the governmental responsibility or function be converted to planning, guidance and motivation. Doubtlessly, such a transition is supported by the good interaction between government, society and market, instead of the governmental enforcement and command.

\section{The Rise And ReCOnstruction OF Modern REGULATORY STATE}

The concept of regulatory state stresses that the major national function is to formulate all sorts of legislation, specifications and standards, and undertake the administrative and supervisory responsibility, during the economic and social development process [2]. Therefore, the positioning of regulatory state is mainly the rule maker, executive supervisor, macro control and other relatively neutral role, the government does not directly get involved with and participate in the operation of market economy in principle [3].

\section{A. The Rise of Modern Regulatory State}

The regulatory state was initially originated from USA. However, at present, the regulatory state has already become the market regulation concept and pattern widely accepted worldwide. Taken the development of USA as an example, USA has experienced the transformation from the laissez-faire state to the regulatory state. At the free competition stage in American history, the government carries out the laissez-faire policy upon the market, while the legislative and judicatory functions are relatively prominent. For the adverse act which is prejudicial to market and society during the market operation process, it is more often than not solved by bringing a lawsuit to the court by individuals. Since the American economic crisis in 1929, the American administrative regulation function has been continuously expanding. After the Second World War, USA established the Environmental Protection Agency, Occupational Safety and Health Administration and other regulators, strengthening the social regulation. After moving into the middle 1970s, Ford Administration and Carter 
Administration implemented the long lasting "Loose Regulation" reform. In the 1980s, Reagan Administration carried out the regulatory reform centered on loosening the economic regulation. In other European countries, the establishment of large-scale regulatory states mainly occurred after 1970s. The concept of regulatory state firstly emerged in the UK. Besides, under the background of de-nationalization, loosening regulation and effective administration of social and economic affairs in the context of globalization, the concept of re-regulation-oriented regulatory state was widely accepted by all states in Europe. In the end 1970s, based on the reference of USA experiences, the UK conducted the reform on regulatory system and continuously established a lot of regulators, such as Civil Aviation Authority, Health and Safety Commission, Independent Broadcasting Authority, and etc. In the end 1980s, the UK established the Telecommunications Office, Office of Gas Supply, Office of Water Services, Office of Electricity Regulation, and etc. To some extent, such organizations represent the government's legal regulation upon the private industrial circles. In 1978, the France established the first regulator, CNIL. Afterwards, many regulators were also successively established [4].

\section{B. Reconstruction of Modern Regulatory State}

USA practiced to loosen the regulation since the 1970s, which had a significant influence upon the world. However, in recent years, with regard to many problems occurred in economic and social development and operation, people begin to constantly rethink the disadvantages of loosening the regulation. Particularly since the occurrence of American financial crisis, many far-sighted figures provided more criticisms against loosening the regulation, believing that the USA-led developed market economy loosened the regulation in a much faster and further manner. At present, with regard to the market regulation concept in all states, the reconstruction of regulation has already become a basic consensus.

Organization for Economic Co-operation and Development (OECD) has offered some schemes and proposals with regard to the regulatory reform, which collectively reflects on the new concept of "Regulatory State". It was pointed out in The OECD Report on Regulatory Reform published in 1997 that the regulation pattern of states in OECD had experienced three phases, namely, Deregulation, Regulatory Reform, and Regulatory Management, from 1980s to the early 1990s.

With the efforts and attempts upon the reconstruction of regulatory state, how to achieve the effective governmental regulation, has already become the basic requirements of economic and social development. Therefore, the market economy is not about whether the governmental regulation is required, but about what to regulate, how to regulate, which method shall be applied for regulation, and whether the regulation is effective. Considering that the laissez faire featured loose regulation has already been proved to be against the economic and social development trend, it has already become the focus of reconstructed regulatory state operation for the government to reconstruct the regulatory system and safeguard the good operation of market economy, by centering on the effectiveness.

\section{Regulatory State in Context of China}

Traditionally, China's market economy management pattern belongs to the regulatory government pattern, while the national economic management activities are mainly conducted by the administrative body through adopting the strong regulatory methods, such as command enforcement, obedience, and etc. Since the reform and opening up, market has played an increasingly prominent role in resources allocation. Our knowledge about the market force has already transformed from the previous basic role to the decisive role, which symbolizes that our understanding about market function has an essential leap. In the course of the current commercial system reform and state-owned-enterprises reform, it is stressed that the market access regulation shall be loosened and the interim and post-event regulation shall be strengthened. With regard to the state-owned-enterprises reform, it is also stressed that the state-owned assets regulation and market regulation shall be separately enforced as per the category pattern of those dedicated to public welfare and for-profit entities. Therefore, the direction of China's regulation reform shall put more emphasis on the Do's and Don'ts of Government Marketing. The Don'ts refers to constantly loosening the market access within the competitive field, while the Do's places more stress on the interim and post-event regulation, including not only the anti-monopoly and other economic regulation within the economic fields, but those social regulations that are against the social actions. Our ongoing new market regulation system also focuses more on the social co-governance, information disclosure, credit constraint and other governance methods that are not seriously taken by the regulators.

Such changes and trends occurring in the market regulation field, makes China's market regulation highly consistent with the concept of regulatory state. In the course of economic and social reform, great changes have already occurred to the relationship between government, economy and society. The government gradually disappears from the overall economic and social regulation, giving way to market and society. Besides, the government's economic management function will also transform from the direct control to market regulationcentered management. This also demonstrates that China is moving from the almighty regulatory government to the regulatory government.

\section{WhAt Is EFFECTIVE REgULATION}

In the course of reconstructing the regulatory state, OECD attaches more importance to the "Problem Solver" type regulation, namely, effective market regulation. For the effectiveness of market regulation, the attention shall be paid to the following significant factors:

\section{A. Publicity of Regulatory Objectives}

The regulatory objective is the final effect and purpose pursued by the market regulation. As the basis of validity of governmental regulation, the relevant regulatory legislation shall explicitly stipulate the objectives of market regulation. The overall regulatory objectives are to safeguard the integrated social interest, further promoting the formation of an 
efficient, fair, safe and stable market. Therefore, the market regulatory objectives of all countries are almost consistent, mainly including: to protect the public interests, safeguard the market security and stability, and maintain the market operation order and fair competition. Metrology Provides the Technical Conformity Evidence for Quality

\section{B. Diversification of Regulatory Methods}

As per the intervention intensity of regulators, the regulatory methods may be divided into three categories: class 1 , the regulatory tools with greater intervention intensity, such as approval, permit and others; class 2, the regulatory tools with intermediate intervention intensity, such as all sorts of compulsory standards; and class 3 , the regulatory tools with the least intervention intensity. For the class 3 , the regulators will not directly define the rights and obligations of actor. Instead, the regulators would like to guide the behaviors of market body through the compulsory information disclosure and incentive regulatory measures [5]. Thus, the government will distinguish the regulatory methods with the high, medium and low intensity as per the characteristics of different sectors and variable industries. For the competitive market, the regulatory tools with less intervention intensity will be generally adopted. In principle, the market access and price regulation will be open, while the emphasis shall be put on the regulation within the technology, safety, information and other aspects. Meanwhile, as to the special markets and sectors (for instance, finance, food and drugs safety, environmental protection, and etc.), the regulatory methods with the greater intervention intensity shall be adopted. Especially, the governmental preevent regulation shall be strengthened, while the standards, information and safety regulation and other mechanisms on such a basis. Besides, with regard to the natural monopoly industries, the regulatory methods with the greater intervention intensity shall also be adopted to strengthen the market access control, especially the price regulation, so as to prevent the monopoly enterprises from abusing its privileged position, enforcing the price monopoly acts, and damaging the consumer interests.

\section{Regulatory Transparency \& Accountability}

The transparency means that the regulatory objectives, framework, decision, basis, data and other information must be disclosed to the public in a complete, convenient, and timely manner, promoting the realization of regulatory objectives. Under the requirements of transparency, regulators and the regulated shall fully exchange the information and negotiate with each other. The regulators shall provide the adequate activity information of its organization, fulfill its regulatory functions in a transparent and responsible manner, and be responsible to the regulatory results. Accountability is closely related to the transparency. The regulators shall rely on the public interest, and adopt the regulatory measures in favor of the economic and social development. They shall be responsible not only to the statutory legislature and relative governmental department, but the regulated and the public. Certainly, the regulators also must assume the responsibility upon their regulatory process, which requires a series of system arrangements, such as the legislative and administrative supervision, strict process regulations \& information disclosure, and etc.

\section{Diversification of Regulatory Body}

With regard to the market regulation, the government has the great limitations, such as the regulatory information asymmetry, insufficient regulatory motivation, the adequate regulatory authority, and etc. In order to solve such problems, it is not enough to only rely upon the government to enforce the regulatory activities. The development of modern economic society requires constructing the social co-governance pattern featured with the multi-subject joint participation, while the market regulation must also follow this development trend. Therefore, it is required to introduce the multi-subjects and strengthen the regulatory effectiveness. Thus, the regulators, industrial associations, enterprises, the public and other social forces shall be mobilized, so as to enhance the market efficiency and performance.

\section{MOdERn Market Regulation System AND SOCial CO-GOVERNANCE}

\section{A. Social Control System under the Perspective of Effective Regulation}

The "Multi-Subject Co-Governance" pattern within the market field shall not only include the active engagement of public administration authority, social organizations and individuals, but include both the command, enforcement and other formal regulatory methods used by the public authority, and the equal negotiation, social self-governance, public engagement and other informal methods.

Although the market is a sort of efficient resources, the market failure still becomes a necessity, due to the existence of information asymmetry, market externality, business cycle, public goods, and monopoly phenomenon. In any society where the absence of state power, all people will rationally come to a conclusion that such a society will be in an endless status of chaos [6]. Therefore, the government regulation in the traditional sense is not only the necessary composition in the state operation, but the important choice of achieving the optimum allocation of resources when the customer service market fails. However, the administration-oriented single center regulation pattern is subject to the current status of economic and social development, governmental capacity, information \& resources, and other constraints, which may strangle the economic \& social vitality due to the governmental over-regulation, or may not effectively control the harmful factors in the course of economic \& social development, and other governmental failure problems. In contrast to the single center governance, the multi-center-governance-based social co-governance has many advantages, which can properly make up for the deficiency of single center governance.

Under the multi-center governance pattern of multi-subject co-governance, the social control system has its own rules and unique composition. The American scholar Robert .C .Ellickson believes that a social control system may fall into three types, namely, first-party control (self-control), second-party control (negotiation \& consultation), and third- 
party control (organizational control and state control) [7]. Besides, such a social control system can also be used to interpret the social control over human behaviors under the market conditions [8]. During the operation process of market economy, the regulatory objectives may also be achieved through controlling and adjusting the acts that may do harm for the economy and society by the multi-subjects inclusive of the government.

\section{B. First-Party Control: Self-Discipline-Based Control}

The social individuals are the cells to form the society. The relationships among all our human beings are mutual interdependence [9]. Caring for or considering the benefits of others, is the essence of morality [10]. It is the foundation of market operation that the market subjects are honest and trustworthy, and subject to all sorts of trading conditions determined based on the rational judgment of both parties. Basically, the maintenance and healthy development of market order is subject to the individual integrity and behavior rationality of the entire market. The market order is derived from the multi-subject rationality and proper arrangement of power based on the common moral identity [11]

The best mechanism of human behavior control is rooted from the actor's respect to the interests of others and social public interests. It is the fundamental solution to control the inherent defects of "Economist" by means of legal regulation, social regulation, moral education and other formal behaviors. In modern society, it is the foundation of economic and social development by cultivating the citizens with the good legal consciousness and moral cultivation. However, in the market regulation, the emphasis on the self-discipline of market subjects is also the foundation to build the new-style regulation system.

\section{Second-Party Control: Consensus-Based Control}

In market operation, the agreement enables both parties to have a much stronger expectation upon the trading results. In case that one party violates the contract, the other party may request relief as per the corresponding contract laws. Therefore, in the trading relationship between market subjects, the consensus based mechanism enables the control of the relative party over the other party's behaviors. In modern market economy, the government can not only adopt the vertical command, control and other methods to regulate the market subjects, but adopt the equal consultation and competition mechanism and other methods to achieve the governmental policy objectives and regulation intentions. For instance, in the ecological treatment, the governmental contract system is generally introduced and used as a significant constraint upon the relative party. Japan is the first country to use the environmental contract as the methods to control the environmental pollution and environmental destruction. Japan places emphasis on the application of private pollution prevention agreements which regulate the discharge standards much stricter than the laws. Such an agreement under the coordination of the public pressure plays a convincing role in preventing from the industrial discharge. Similarly, in China, the letters of environmental protection responsibility, the letters of closing down the outdated production facilities, and others will be signed between the superior government and the inferior government, and the government and enterprises, all of which are the reflection methods of environmental responsibility contracts.

\section{Third-Party Control: External Force-Based Control}

\section{1) Industrial Self-Discipline}

The industrial associations and chambers of commerce have the strong social governance function. With the aid of articles of association of industrial associations, the members adhere to the common goal and almost consistent objectives, are gathered around the industrial associations, and maintain the integrated social interests through the self-discipline, rights protection and other mechanisms. Based on their visceral connection to the industrial association and chambers of commerce, the members are subject to the necessary selfgovernance regulations on the voluntary basis, and the selfdiscipline \& punishment of the industrial associations and chambers of commerce. The industrial associations and chambers of commerce will participate in the commercial behavior management of their own members, which will be further coordinated with the formal national governance mechanism and effectively achieve their management upon the market subjects and governance upon the market order. By means of their own information or technology and other advantages, the industrial organizations will participate in the governmental decision-making process or the development process of public policy, so as to restrict the governmental regulatory behaviors and avoiding the occurrence of "Governmental Failure”.

\section{2) Social Supervision}

The market is a sort of ethical system [12]. The market economy is neither beyond the ethics, nor against the ethics. In contrast, it needs a certain ethical supports. "The ethical requirements of market economy are the lowest level of ethics". The subjects and methods of ethical evaluation come from the society, while the controller is the public and the control method is the pressure from public opinions. In the course of modern society development, the credit rating agencies, independent auditing agencies, social media and other mechanisms play the active roles in the social supervision process. Under the background of commercial reform, the compulsory information disclosure mechanism and the corresponding social credit constraints, provide much better conditions for social supervision, constituting the significant constraints upon the dishonest behaviors of the market subjects.

\section{3) Governmental Regulation}

Due to the complexity and extensive connectivity of the modern society operation, the regulators generally need to use the social co-governance mechanism to strengthen the regulation and enhance the regulatory effectiveness. In the context of the current legislation and regulation, the government may have the enough space to make the most of its intelligence and apply the multi-control-subjects and multicontrol-methods to the regulatory practice by developing the corresponding legislations and enforcing the corresponding policies. Thus, the current legal mechanism will be properly integrated while the effective control schemes will be formed. 


\section{CONCLUSION}

This round of reform of the State Council bodies will adopt the unified market regulation and building a unified, open, competitive and orderly modern market system, by establishing the State Administration for Market Regulation. As mentioned above, the market regulation shall not only rely on the administrative regulation, but play the supervision roles of the market and society, so as to achieve the social co-governance of market supervision. At present, China's social engagement and regulation are seriously not in place. In view of the international experience, NGO, industrial organizations, chambers of commerce and other social forces play a unique role in market regulation. China has the deep-rooted "There are chambers of commerce for merchants and industrial associations for variable trades". The industrial associations and chambers of commerce had played the irreplaceable roles in promoting the credit in enterprises and self-discipline. Under the current regulatory system, the administrative inclination of industrial associations and chambers of commerce become very serious and lacks the credibility. Therefore, it is difficult to play the industrial self-discipline role.

In order to fully playing the self-discipline role of industrial associations and chambers of commerce, it is necessary to promote the existing chambers of commerce and industrial association to "separate the chambers of commerce and industrial associations from administration", support the private enterprises to establish all sorts of chambers of commerce and industrial association by the voluntary association means, and promote the "multi-associations in one industry" policy, forming the effective competitive mechanism and timely eliminating the chambers of commerce and industrial associations short of industrial self-discipline.

Besides, it is also necessary to actively promote the legal representative commitment system and establish the post-event regulatory new mechanism based on the enterprise credit and self-discipline. As to the matters that the approval must be pending, the responsibility commitment letter and list of approval requirements shall be provided to the applicant enterprises, while the legal representatives shall be responsible for the material authenticity. The approval department may issue the approval letters and licenses on the spot or on the same day. Afterwards, the regulators may carry out the on-site verification in a random manner. In case that any enterprise fraud phenomenon is found, such enterprise will be severely punished.

\section{ACKNOWLEDGMENT}

This research was financially supported by the National Key Research and Development Program (2016YFF0204206), National Standards Revision Project (572018B-0046) and the President Foundation of CNIS (572018Y-5937)

\section{REFERENCES}

[1] Michael Moran, "Review Article: Understanding the Regulatory State", British Journal of Political Science, 2002. 32

[2] LIU Peng, “Campaign Style Regulation and Regulatory State Construction: Based on the Case Study of Food Safety Special Remediation Action”, Chinese Public Administration, 2015, (12): pp.118-124

[3] Edward L. Glaeser, and Andrei Shleifer. "The Rise of the Regulatory State",Journal of Economic Literature,2003, Vo1 XLI: pp.410-425.

[4] Giandomenico Majone, "The Rise of the Regulatory State in Europe", West European Politic, 1994, Vol. 17, Issue 3:pp.83-84.

[5] Anthony. I. Ogus, "Regulation: Legal Form and Economic Theory", Translated by LUO Meiying, China Renmin University Press, 2008

[6] Kenneth. F. Warren, “Administrative Law in the Political System (Third Edition)”, Translated by WANG Conghu et al, China Renmin University Press, 2005

[7] Robert. C. Ellickson, "Order Without Law: How Neighbors Settle Disputes”, Translated by SU Li, China Renmin University Press, 2016

[8] WANG Wei, “Legal Logic and Mechanisms for Market Regulation”, Law Press China, 2016

[9] Jiang Shan. Cooperation and self-sufficiency: The general theory of the historical logic of law and economy. China University of Political Science and Law press,2002.

[10] Zhang Hengshan.Discussion on legal principle. China University of Political Science and Law press.2009.

[11] Jiang Wuzhen. The legal philosophy of the rule of law of market supervision,Law Science, 2013,(10). pp.29.

[12] A. Allan Schmid, Property, Power and Public Choice: An Inquiry into Law and Econo mics, Translated by HUANG Zuhui et al, Shanghai SDX Joint Publishing Company, 1999 